\title{
Model of People's Perception of Water Treatment Equipment: Preliminary Study of the Lake Water Treatment Plan in Gresik Dry Land Area, Indonesia
}

\author{
Esthi Kusdarini ${ }^{1}$, Suyadi ${ }^{2}$, Bagyo Yanuwiadi ${ }^{3}$, Lukman Hakim $^{4}$ \\ \{suyadi@ub.ac.id²\}
}

Universitas Brawijaya, Indonesia ${ }^{1,2,3,4}$

\begin{abstract}
Water treatment equipment which is supplied in Gresik, East Java, Indonesia by the government in the development of lake water has been overlooked. The problems are occurred in this area because the people are not ready to adopt the equipment. Measurement is required in order to successfully adopt the equipment, moreover, understanding people's perceptions of the government's instrument to be used. The aim of this study is developing a model of people's perception of the equipment and the purpose is understand the factors that effect of people's perception. It is relating to the plan of implementation of water treatment facilities in the lake water which is used by the people. Primary data from 248 lake water users were gathered randomly based on the village's region in this research. Descriptive statistics and regression analysis were used to analyze the data of this research. In this study, the model developed could explain $77.8 \%$ of the people's perception variance. Knowledge, wish, belief, and satisfaction affect to the people's perception in positively and significantly. The results show that knowledge of clean water, a desire for good living, confidence in the equipment's ability to work, and satisfaction with the equipment's economic value had significant consequences for people's perceptions of the equipment. Therefore, the information of contaminant risks, real conditions of lake water parameters, requirements for clean water and drinking water, community involvement in the procurement of sample equipment, socialization of sample equipment operation and socio-economic community surveys need to be disseminated.
\end{abstract}

Keywords: Lake Water, Perception, Regression Analysis, Water Treatment Equipment.

\section{Introduction}

There are several lakes that can hold rainwater for the surrounding community as a source of clean water and drinking water in Gresik dry land area. Because of the difficulty of discovering groundwater sources in this region, the presence of these lakes is very useful to the society around. However, the findings of the laboratory showed that lake water did not satisfy clean water and drink water criteria. Lake water is contaminated by the flow of surface water that releases pollutants such as surfactant, organic matter, E. Coli, and total coliform [1]. The societies must reduce the level of turbidity, water lake color, and lake water will obtain. If the societies do this treatment, the quality of lake water will meet the requirements of clean water or drink water as intended. For this reason, it is necessary to treat lake water before the communities consume this water. 
Water treatment requires a treatment plant for water. Water treatment equipment that suitable for the treatment is a water filter with manganese greensand, zeolite, and activated carbon media. The process of filtration that works on the equipment separates the solid from the liquid. The solids will be held in the media, while the liquid will escape. Manganese greensand, zeolite and activated carbon are appropriate filter media which is used to decrease contaminations in lake water. All three media operate to decrease fluid solids, heavy metals and organic compounds and those are not too large [2][3][4][5]. Furthermore, to reduce E. Coli and total coliform content, the disinfection process is carried out using chlorine.

Even though, appropriate water treatment tools have been discovered in the research area for the treatment of lake water, the communities do not necessarily want the equipment to be accepted. It is possible that there will be no adoption of instruments or technology that will be implemented for societies. It can be seen from the presence of water treatment equipment from the government that was abandoned on the edge of the lake Metatu Village, Gresik, East Java, Indonesia. This could be because there was no socialization regard to equipment for water treatment. Furthermore, the failure of equipment adoption may happen to customer disappointment in the equipment's quality and cost [6][7].

People's perception for new equipment or technology is one of factors affects people's decision to adopt new equipment or technology [6][7][8]. Factors determination that influence perceptions or independent variables in the model based on previous studies that explained the factors of education level, knowledge, characteristics of equipment, and prices of equipment [9]. And those factors affected one's perception of an equipment or technology $[10][11][12][13][14][15]$. In previous studies, there were explained that the equipment's price had a positive and significant impact on the equipment's perception [12][10], but the equipment's price was not connected with it and consumers knew the benefits of the equipment. Furthermore, in this study, the equipment's price factor changed with the equipment's economic value so that there is a merger between the equipment's price and benefits. Therefore, this study is designed to develop a model of people's perception of water filters and explicitly, this research studies about factors that affect water users' perception that use lake water in this dry land in Gresik, Eats Java, Indonesia toward water filter is used to treat lake water which is consumed by the society.

\section{Methods}

\subsection{Conceptual Framework Model and Hypothesis}

The conceptual framework of the model consists of four independent variables or factors. There are knowledge of clean water (X1), a desire for good living (X2), confidence in the equipment's ability to work (X3) and satisfaction with the equipment's economic value (X4); and one dependent variable: people's perception (Y). 


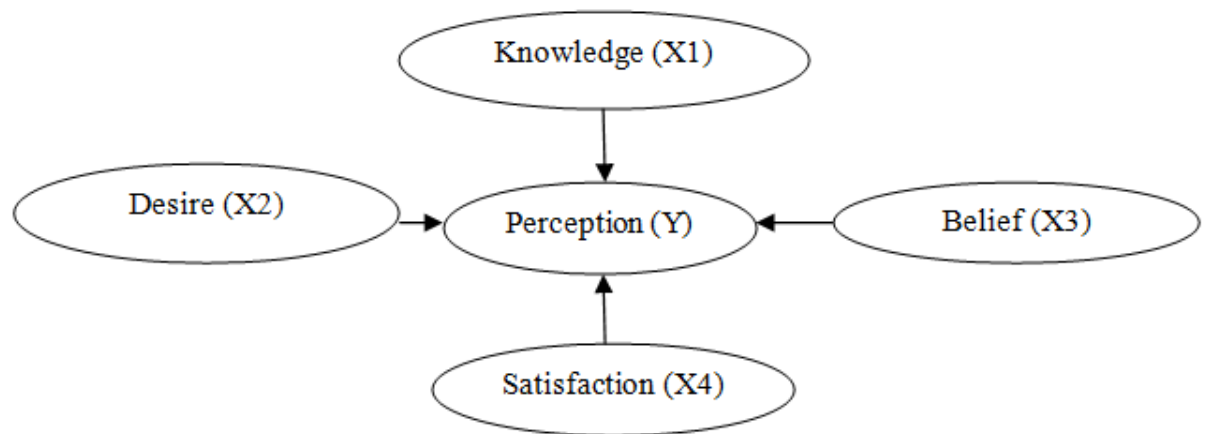

Fig. 1. Conceptual framework of the model of people's perception of the water treatment equipment

Furthermore, there are 4 hypotheses that will be tested in the study:

H1 : People's perception is influenced positively by knowledge

H2 : People's perception of equipment is influenced positively by desire

H3 : People's perception of equipment is influenced positively by beliefs

H4 : People's perception of equipment is positively influenced by satisfaction

\subsection{Data collection}

Researchers obtained Primary data from respondents' responses to questionnaire questions. Random selection of participants was made on the basis of the village region (Random Sampling Cluster). For this study, the population includes communities that consume lake water in three villages, such as Metatu Village, Sirnoboyo and Kalipadang (Gresik Regency, East Java, Indonesia). The locations of the three villages are presented in Figure 2.

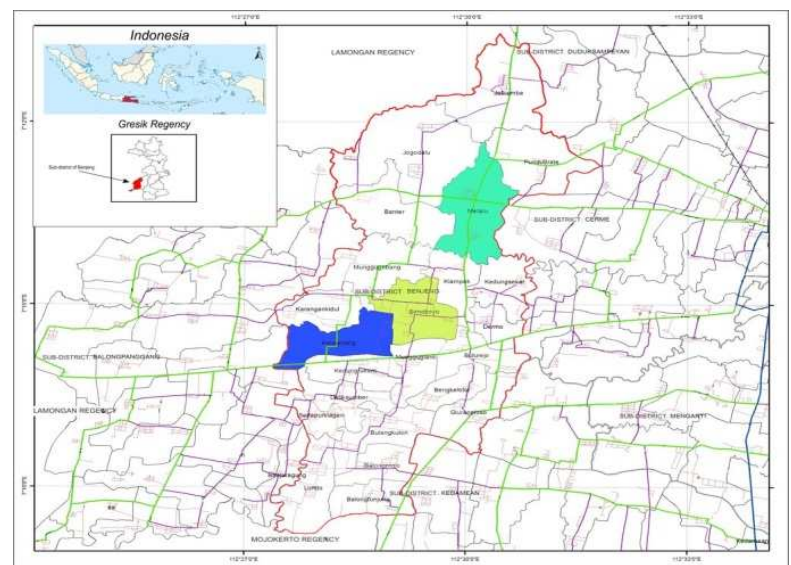

Fig. 2. Location of Metatu (green), Sirnoboyo (yellow), and Kalipadang Village (blue).

There are several activities carried out before the researchers distributed questionnaires in this study, such as the installation of water treatment equipment and the socialization of water treatment equipment to the community around the lake water. The researchers have installed 
three equipment, each positioned at the research site in each village. Figure 3 presents one of water treatment equipment (location of the equipment on the edge of Karangasem Lake, Sirnoboyo Village). There are three types of media arranged from below throughout the water treatment plant which are activated carbon, zeolite, and manganese greensand, While the flow of water from top to bottom. The media used in the water treatment plant is presented in Figure 4.

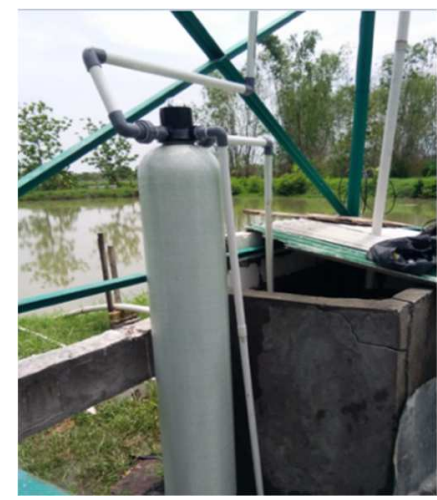

(a)

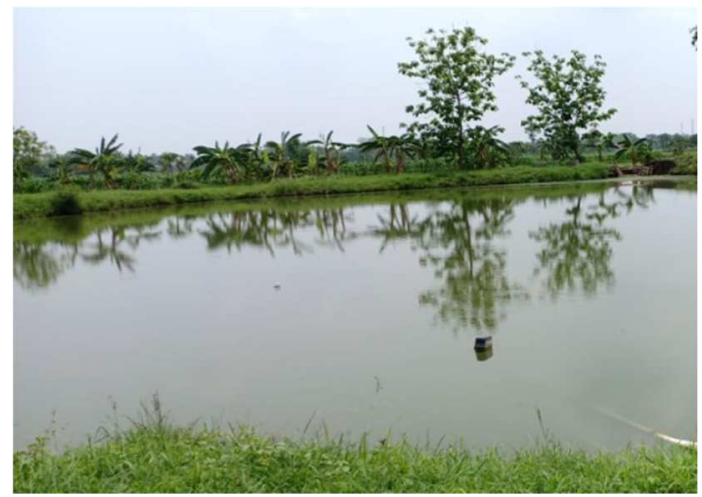

(b)

Fig. 3. (a) Water treatment equipment, (b) Karangasem Lake (Sirnoboyo village)

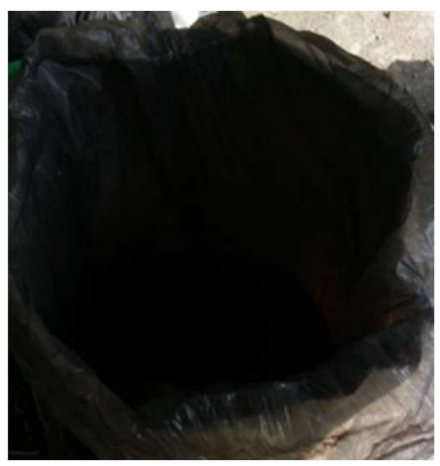

(a)

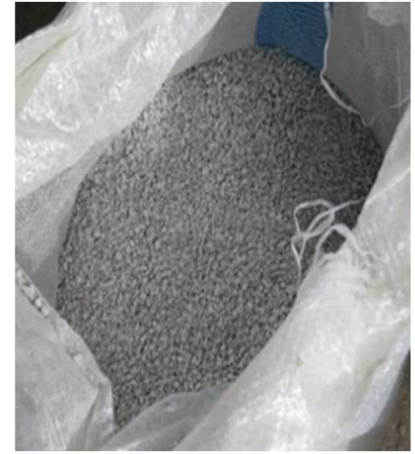

(b)

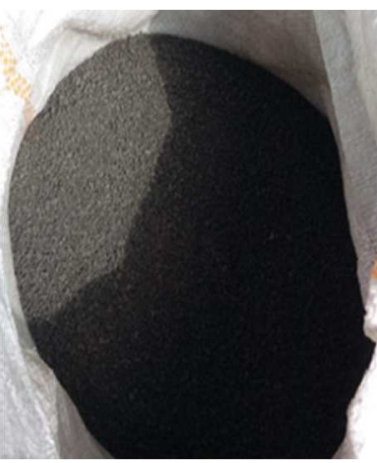

(c)

Fig. 4. Media (a) manganese greensand, (b) zeolite, (c) activated carbon

After the society used water treatment equipment for 1-2 months, the researchers distributed 250 questionnaires to users of the lake water, but there were only 248 sets filled. The responses of the respondents were measured using a Likert Scale from 1 (strongly disagreement) to 5 (strong agreement).

\subsection{Statistical Testing}

Statistical testing uses SPSS software version 23. The first step in statistical testing is to test the validity and reliability of questionnaire questions. If the Pearson correlation coefficient 
$\mathrm{r}_{\mathrm{xy}}$ is higher than the cut-off value or $\mathrm{r}$ table, the issue is proclaimed valid [11]. While the question is declared reliable if Cronbach's alpha is higher than 0.60 [13]. After all the questions raised are valid and reliable, the model will be evaluated using the assumption of normality, heteroscedasticity assumption, and multicollinearity assumption. If the model evaluation has been agreed on, then continue to test the determination and hypothesis coefficient. The normality assumption is issued through the Normal Probability Plot. Hypothesis for normality testing were H0: residuals are normally distributed and H1: residuals are not distributed equally. Test criteria indicated the release of information points spread around the diagonal line and then declared otherwise distributed normally. The researchers will do the testing of heteroscedasticity assumption based on the Glejser Test. The hypothesis of testing heteroskedasticity assumption was $\mathrm{H} 0$ : residuals have homogeneous variants and H1: there are no homogeneous differences in residuals. Residuals have a homogeneous range if all the autonomous variables' likelihood values are higher or equal to the meaningful level $(\alpha=5 \%)$ [11]. Multicollinearity hypothesis uses to test the existence or lack of symptoms of multicollinearity or the existence of a powerful connection between the model's independent variables. The model is reported to have no signs of multicollinearity if the value of the inflation factor of variance (IFV) is less than 10 [14]. This study also assessed the dependent variable's capacity to explain the variety of independent variables expressed in the determination coefficient $\left(\mathrm{R}^{2}\right)$. The model is effective if $\mathrm{R}^{2}$ is 0.67 ; if $\mathrm{R} 2$ is 0.33 the model is mild, and if $R^{2}$ is 0.19 the model is weak [15].

\subsection{Empirical Analysis}

Hypothesis testing uses multiple linear regression analysis (T-test and F-test). The selection of regression analysis is because the impact of several independent variables on the dependent variable has been widely studied in different study [16][17],

$$
Y=a+b 1 X 1+b 2 X 2+\ldots . .+e
$$

Where:

$\mathrm{Y}$ is the dependent variable, which is the variable of people's perception of water filters. $\mathrm{X}$ is an independent variable or factor, such as knowledge (X1), desire (X2), belief (X3), and satisfaction (X4). Whereas a, b, and e are constants.

The test criteria state that if the probability value is less than the level of significant $(\alpha=5 \%)$, then the influence of the independent variable on the dependent variable is stated [11].

\section{Result and Discussion}

\subsection{Characteristics of Respondents}

Respondents in this study were 248 lake water users spread around three villages. There were as many as $55 \%$ males and $45 \%$ female participants. Respondents aged: $16-25$ years were $10 \%, 26-35$ years were $27 \%, 36-45$ years were $29 \%, 46-55$ years were $27 \%$, and 56 years and over were $7 \%$. While high school participants are as much as $28 \%$ primary school, junior high school as much as $25 \%$, senior high school as much as $43 \%$, undergraduate as much as $4 \%$. In addition, participants with revenue below IDR 3,000,000 per month are $85 \%$ and $15 \%$ with revenue above it. 


\subsection{Respondents' Perception}

Respondents' perception to the water treatment equipment was described in Table 1. Table 1 explained that respondents' perceptions to the water treatment equipment was good, it was 4.1706. Respondents' response to clean water knowledge was good, in 4.4435, and respondents' response to the equipment economic value was the worst. The average was 3.8226. In this study, the price of equipment investment to each household was $\mathrm{Rp}$. $150.000,00$ and the societies were able to consume clean water which met the healthy requirements and filled the water aesthetic in daily life. From the price charged, there were few responds from the society. They were $6 \%$ of respondents disagreed, $33.3 \%$ of respondents doubted, $55.2 \%$ agreed, and $16.5 \%$ strongly agreed. The difference in respondents' response was caused by socioeconomic factor [18].

Table 1: Respondents' perception of equipment ( $n=248$ person)

\begin{tabular}{lcccc}
\hline \multicolumn{1}{c}{ Factor } & Minimum & Maximum & Mean & Std. Deviation \\
\hline Knowledge (X1) & 2.00 & 5.00 & 4.4435 & 0.58041 \\
Desire (X2) & 2.00 & 5.00 & 4.3468 & 0.62401 \\
Belief (X3) & 2.00 & 5.00 & 4.2016 & 0.60336 \\
Satisfaction (X4) & 2.00 & 5.00 & 3.8226 & 0.77458 \\
Perception & 2.50 & 5.00 & 4.1706 & 0.43087 \\
\hline
\end{tabular}

\subsection{Statistical Testing}

The validity test showed that all answers were valid in evaluating indices because the coefficient of Pearson Correlation varies from 0.586 to 0.919 , higher than the limit value of 0.361 [11]. While the reliability test shows that all answers are valid because the alpha of Cronbach ranges from 0.929 to 0.946 , so it is higher than 0.60 [13].

The Normal Probability Plot test is used to evaluate the model for normality assumptions. In addition, the hypothesis by the Glejser Test of heteroscedasticity indicates that all indicators generate a probability of $0.220-0.931$ or higher than the level of significant ( $\alpha=5 \%$ or 0.05 ) level [11]. This means that the residuals have a homogeneous range. Thus, the hypothesis of heteroscedasticity is achieved.

Testing the hypothesis of multicollinearity also shows that there are no symptoms of regression coefficients with a VIF value of 1.074 to 1.395 or less than 10 in the model [14]. The next evaluation is to test the determination coefficient to show the variance of the equipment perception factors of people. In the model, the ratio of deterrence or R-square is 0.778 or $77.8 \%$, so the model is strong [15].

\subsection{Empirical Analysis}

Hypothesis testing uses multiple linear regression analysis (T-Test and F-Test) showed that the hypotheses H1, H2, H3, and H4 can be accepted. The results of the partial significance tests (T-Test) are presented in Table 2.

Table 2: Partial significance test results (T test) 


\begin{tabular}{lccc}
\hline \multicolumn{1}{c}{ Factor } & Coefficient & T Statistics & Sig. \\
\hline (Constant) & 0.582 & 4.355 & 0.000 \\
Knowledge (X1) & 0.234 & 9.410 & 0.000 \\
Desire (X2) & 0.315 & 12.779 & 0.000 \\
Belief (X3) & 0.115 & 5.163 & 0.000 \\
Satisfaction (X4) & 0.182 & 9.879 & 0.000 \\
\hline
\end{tabular}

Table 2 shows that the four factors have a lower probability value than the significant level $(\alpha=5 \%)$, so the factors have in addition to the partial significance test (T-test), a simultaneous significance test (F test) was also carried out. Significance test results simultaneously produce a calculated $\mathrm{F}$ value of 213,378 with a probability of 0,000 . The test results show the probability $<$ level of significance $(\alpha=5 \%)$ so that the four autonomous factors have a substantial impact on the dependent variable [11].

\subsection{Research Implications}

The results showed that knowledge of clean water and water treatment [18]; the desire to live healthily and then the society uses processed water; confidence in the equipment's practicality and work [12]; satisfaction with economic value and location selection of equipment installation have significant consequences for the people's perception of equipment. Therefore it is necessary to conduct socialization regarding the negative effects of contaminants on the human body; the results of laboratory analysis of the parameters of the lake they consume, the requirements for the parameters of clean water and drinking water based on the Regulation of the Minister of Health of the Republic of Indonesia and WHO; community involvement in the procurement and socialization of equipment; community socioeconomic survey to support the procurement and adoption of equipment.

\section{Conclusion}

The model of people's perception of water treatment equipment-generated from this study explains that the factors of knowledge, desires, beliefs, and satisfaction affect the perception of the equipment positively and significantly. This model is useful in explaining the variance of the perception variable, which is 77.8 percent, but in further studies, this model still needs to be refined. Regarding knowledge, satisfaction, and faith, the most important variable on equipment perception is desire. Satisfaction indicators with the economic value of the instrument hypothesized in this study have been shown to have a positive and significant impact on the people's perception. As further studies are needed on procurement expenses and operational equipment that it does not affect if it is charged to the community. Furthermore, the study needs to be conducted on the advantages that the community can feel after lake water treatment. This is to support the continued implementation of water treatment equipment and clean water accessibility that meets the demands of the Republic of Indonesia's Ministry of Health and WHO. The method used in this study can also be applied in other areas with different water quality, types of water treatment equipment, community characteristics, and the environment.

\subsection{Acknowledgment}


This research was funded by the Education Fund Management Institute, Ministry of Finance of the Republic of Indonesia.

\section{References}

[1] E. Kusdarini, S. Suyadi, B. Yanuwiadi, and L. Hakim, "Analysis of Water Sources Availability and Water Quality in Dry and Rainy Season in Dry Land Areas, North Gresik, Indonesia," Pollut. Res., vol. 38, no. 4, pp. 58-65, 2019.

[2] J. G. Outram, S. J. Couperthwaite, and G. J. Millar, "Comparitve analysis of the physical, chemical and structural characteristics and performance of manganese greensands," J. Water Process Eng., vol. 13, pp. 16-26, Oct. 2016.

[3] G. Moussavi, S. Talebi, M. Farrokhi, and R. M. Sabouti, "The investigation of mechanism, kinetic and isotherm of ammonia and humic acid co-adsorption onto natural zeolite," Chem. Eng. J., vol. 171, no. 3, pp. 1159-1169, 2011.

[4] E. Kusdarini, A. Budianto, and D. Ghafarunnisa, "Produksi Karbon Aktif dari Batubara Bituminus dengan Aktivasi Tunggal H3PO4, Kombinasi H3PO4-NH4HCO3, dan Termal," Reaktor, vol. 17, no. 2, pp. 74-80, 2017.

[5] A. Budianto, E. Kusdarini, S. Effendi, and M. Aziz, "The Production of Activated Carbon from Indonesian Mangrove Charcoal," Mater. Sci. Eng., vol. 462, pp. 1-8, 2019.

[6] B. Jones, E.E.; Kannouse, D.E.; Kelley, H.H.; Nisbet, R.E.; Valins, S; and Weiner, Atribusi: Pasrah Penyebab Perilaku. Morristown, NJ: Umum Tekan Belajar, 1972.

[7] M. S. Sigit, Suyadi, M. S. Djati, and B. Yanuwiyadi, "The Empowerment of Communities around the Forest of Bawean Island Animal Preserve for the Rescue of Bawean Deer (Axis Kuhlii)," IOSR J. Agric. Vet. Sci., vol. 9, no. 7 Ver. II, pp. 23-29, 2016.

[8] Hariyono, Suyadi, L. Hakim, and B. Yanuwiadi, "The Role of Environmental And Behavior Factors to dengue Fever IncidentsNo Title," J. Appl. Environ. Biol. Sci., vol. 6, no. 4, pp. 1-8, 2016.

[9] T. S. Rini, A. Rachmansyah, A. W. Muhaimin, and S. Suyadi, "Participation of waste pickers in waste management: A case study at randegan landfill Mojokerto, Indonesia," World Appl. Sci. $J .$, vol. 25, no. 7, pp. 1036-1043, 2013.

[10] I. A. Bediako, X. Zhao, H. A. Antwi, and C. N. Mensah, "Urban water supply systems improvement through water technology adoption," Technol. Soc., vol. 55, pp. 70-77, Nov. 2018.

[11] V. W. Sujarweni, SPSS Untuk Penelitian. Yogyakarta: Pustaka Baru Press, 2015.

[12] K. A. Darkwah, J. D. Kwawu, F. Agyire-Tettey, and D. B. Sarpong, "Assessment of the determinants that influence the adoption of sustainable soil and water conservation practices in Techiman Municipality of Ghana," Int. Soil Water Conserv. Res., vol. 7, no. 3, pp. 248-257, Sep. 2019.

[13] J. . Hair, R. . Anderson, R. . Tatham, and W. . Black, Multivariate Data Analysis, Fifth edit. New Jersy: Prentice Hall Inc., 1998.

[14] M. H. Kutner, N. C.J., and N. J., Applied Linear Regression Models, Fourth Edi. New York: The McGraw-Hill Company, 2004.

[15] W. Chin, The Partial Least Square Approach for Structural, in George A. Marcoulides (Ed.), Modern Methods for Business Research. Lawrence Erlbaum Associates, 1998.

[16] J. Chantana, Y. Kawano, A. Kamei, and T. Minemoto, "Description of degradation of output performance for photovoltaic modules by multiple regression analysis based on environmental factors," Optik (Stuttg)., vol. 179, pp. 1063-1070, Feb. 2019.

[17] J. J. Peng, "Factors Affecting Carbon Emissions in the Construction Industry based on STIRPAT Model: Taking Henan Province of China as an Example," Nat. Environ. Pollut. Technol., vol. 18, no. 3, pp. 1035-1040, 2019. 
[18] M. Sileshi, R. Kadigi, K. Mutabazi, and S. Sieber, "Determinants for adoption of physical soil and water conservation measures by smallholder farmers in Ethiopia," Int. Soil Water Conserv. Res., Aug. 2019. 